Original Research Paper

\title{
Convective Heat Transfer and Thermal Performance in a Circular Tube Heat Exchanger Inserted with U-Shaped Baffle
}

\author{
${ }^{1}$ Amnart Boonloi and ${ }^{2}$ Withada Jedsadaratanachai \\ ${ }^{I}$ Department of Mechanical Engineering Technology, College of Industrial Technology, \\ King Mongkut's University of Technology North Bangkok, Bangkok 10800, Thailand \\ ${ }^{2}$ Department of Mechanical Engineering, Faculty of Engineering, \\ King Mongkut's Institute of Technology Ladkrabang, Bangkok 10520, Thailand
}

Article history

Received: 29-06-2017

Revised: 19-07-2017

Accepted: 5-09-2017

Corresponding Author: Withada Jedsadaratanachai Department of Mechanical Engineering, Faculty of

Engineering, King Mongkut's Institute of Technology

Ladkrabang, Bangkok 10520,

Thailand

Email: kjwithad@kmitl.ac.th

\begin{abstract}
Numerical investigations on flow structure and heat transfer characteristic in a heat exchanger tube fitted with U-shaped baffle are presented. The U-shaped baffle is created from the concepts of orifice and inclined baffle. The influences of the baffle height $(b / D=0.05,0.10,0.15$, 0.20 and 0.25$)$ and flow attack angle $\left(\alpha=20^{\circ}, 30^{\circ}\right.$ and $\left.45^{\circ}\right)$ of the Ushaped baffle on heat transfer, pressure loss and thermal performance are considered. The finite volume method with SIMPLE algorithm is selected to solve the present problem. The numerical results are reported in terms of flow visualization and heat transfer behavior. The performance analysis for the tube heat exchanger inserted with the U-shaped baffle is also reported. As the numerical result, it is found that the insertion of the U-shaped baffle help to improve the heat transfer rate and thermal performance higher than the smooth tube with no baffle. The increments of heat transfer rate and pressure loss are around 1-8.7 and 1-29 times over the smooth tube, respectively. Additionally, it is detected that the $45^{\circ} \mathrm{U}$-shaped baffle with the $B R=0.2$ gives the highest thermal enhancement factor around 2.9 at the highest Reynolds number, $R e=1200$.
\end{abstract}

Keywords: Baffle, Thermal Performance, Heat Transfer Rate, Heat Exchanger, Finite Volume Method

\section{Introduction}

The thermal performance improvement in various types of the heat exchanger is frequently found in many industries. The performance improvement in the heat exchanger or heating/cooling channel can help to save production cost and thermal energy of the system. The thermal improvement can divide into two techniques; active and passive techniques. The passive technique is a popular way to improve the thermal performance and heat transfer rate in the heat exchanger due to the passive technique not requires the additional power into the system. The passive technique is the installation of the vortex generator in the tube/channel heat exchanger to generate the vortex, swirling flow and to disturb the thermal boundary layer on the tube wall. The selection for the type of the vortex generator depends on the application of the heat exchanger.

The circular ring (like orifice) is widely installed in the heating/cooling system to augment the heat transfer rate and performance. Kongkaitpaiboon et al. (2010a) experimentally studied on heat transfer and friction loss in a circular tube heat exchanger with circular-ring vortex generators. The effects of the diameter ratios (diameter of the orifice to the diameter of the tube) and pitch ratios $(P / D)$ were investigated for turbulent region, $R e=4000-20,000$. They reported that the heat transfer augmentation is around $57-195 \%$ when compared with the smooth circular tube without vortex generator. The selection of the conical-ring to improve the heat exchanger was also reported by many researchers (Yakut and Sahin, 2004a; 2004b; Durmus, 2004; Eiamsa-ard and Promvonge, 2006a; 2006b; Promvonge and Eiamsa-ard, 2007a; 2007b; 2007c; 2007d; Kongkaitpaiboon et al., 2010b; Ozceyhan et al., 2006; Akansu, 2006; Kiml et al., $2003 ; 2004)$. They found that the conical-ring in the heat exchanger enhances heat transfer rate and thermal efficiency, but also increases very large pressure loss, especially, at low diameter ratio (low flow area).

The literature reviews for the numerical investigation on flow and heat transfer in the channel heat exchanger inserted with baffle are shown as Table 1 .

As the previous works, the present generator is designed with the main aim to support the installation and maintenance methods in the real system and also 
gives high heat transfer rate and thermal performance as the baffle turbulator. The U-shaped baffle is a combination of the inclined baffle and orifice plate (circular ring). The distinctive advantages for the inclined baffle are to give both high thermal performance and heat transfer rate, while the orifice plate allows easy implementation in real system.

In the current investigation, the effects of the baffle height and flow attack angle for the U-shaped baffle on heat transfer rate, pressure loss and thermal performance are considered for the laminar regime at $R e=100-1200$. The numerical method (finite volume method) is selected to investigate the present problem. The numerical method may help to describe the mechanisms on the test section that the way to develop the vortex generator in the system. The performance assessment for the tube heat exchanger inserted with the U-shaped baffle is also reported.

\section{Physical Geometry of the Tube Heat Exchanger and Arrangement}

The U-shaped baffles are inserted in the circular tube heat exchanger (Fig. 1) in order to increase heat transfer rate and thermal performance. The circular tube diameter, $D$, is around $0.05 \mathrm{~m}$. The length of the periodic module is fixed at $0.05 \mathrm{~m}(=D)$. The U-shaped baffle is created from the concepts of the inclined baffle and orifice.

Table 1. The literature reviews for the numerical investigation on flow and heat transfer in the channel heat exchanger installed with baffle

\begin{tabular}{|c|c|c|c|c|}
\hline Authors & Studied cases & $N u / N u_{0}$ & $f / f_{0}$ & $T E F$ \\
\hline Jedsadaratanachai et al. (2011) & $\begin{array}{l}30^{\circ} \text { inclined baffle Inline, } \\
\text { two opposite walls, square channel } \\
B R=0.2 \\
P R=0.5-2.5 \\
\operatorname{Re}=100-2000\end{array}$ & $1.00-9.20$ & $1.00-21.50$ & 3.78 \\
\hline Kwankaomeng and & $30^{\circ}$ inclined baffle & $1.00-9.23$ & $1.09-45.31$ & 3.10 \\
\hline Promvonge (2010) & $\begin{array}{l}\text { One side, square channel } \\
B R=0.1-0.5 \\
P R=1.0-2.0 \\
R e=100-1000\end{array}$ & & & \\
\hline Promvonge et al. (2010) & $\begin{array}{l}30^{\circ} \text { inclined baffle Inline, } \\
\text { two opposite walls, square channel } \\
B R=0.1-0.3 \\
P R=1.0-2.0 \\
\operatorname{Re}=100-2000\end{array}$ & $1.20-11.00$ & $2.00-54.00$ & 4.00 \\
\hline $\begin{array}{l}\text { Promvonge and } \\
\text { Kwankaomeng (2010) }\end{array}$ & $\begin{array}{l}45^{\circ} \mathrm{V}-\text { baffle Staggered, two opposite } \\
\text { walls, } \mathrm{AR}=2 \text { channel } \\
B R=0.05-0.3 \\
P R=1.0 \\
\operatorname{Re}=100-1200\end{array}$ & $1.00-11.00$ & $2.00-90.00$ & 2.75 \\
\hline Promvonge et al. (2010) & $\begin{array}{l}45^{\circ} \text { inclined baffle Inline-staggered, } \\
\text { two opposite walls, square channel } \\
B R=0.05-0.3 \\
P R=1.0 \\
\operatorname{Re}=100-1000\end{array}$ & $1.50-8.50$ & $2.00-70.00$ & 2.60 \\
\hline Promvonge et al. (2012) & $\begin{array}{l}45^{\circ} \mathrm{V} \text {-baffle Inline Downstream, } \\
\text { two opposite walls, square channel } \\
B R=0.1-0.3 \\
P R=1.0-2.0 \\
\operatorname{Re}=100-2000\end{array}$ & $1.00-21.00$ & $1.10-225.00$ & 3.80 \\
\hline Boonloi (2014) & $\begin{array}{l}20^{\circ} \mathrm{V} \text {-baffle Inline Downstream-Upstream, } \\
\text { two opposite walls, square channel } \\
B R=0.1-0.3 \\
P R=1.0 \\
\operatorname{Re}=100-2000\end{array}$ & $1.00-13.00$ & $1.00-52.00$ & 4.20 \\
\hline $\begin{array}{l}\text { Boonloi and } \\
\text { Jedsadaratanachai (2013) }\end{array}$ & $\begin{array}{l}30^{\circ} \mathrm{V} \text {-baffle Downstream, } \\
\text { One side, square channel } \\
B R=0.1-0.5 \\
P R=1.0-2.0 \\
R e=100-1200\end{array}$ & $1.00-14.49$ & $2.18-313.24$ & 2.44 \\
\hline $\begin{array}{l}\text { Jedsadaratanachai and } \\
\text { Boonloi (2013) }\end{array}$ & $\begin{array}{l}45^{\circ} \text { Discrete }-\mathrm{V}-\text { baffle Downstream, } \\
\text { diagonally, square channel } \\
B R=0.05-0.20 \\
P R=1.0-1.5 \\
\operatorname{Re}=100-1200\end{array}$ & $1.40-8.10$ & $2.50-36.00$ & 2.50 \\
\hline
\end{tabular}




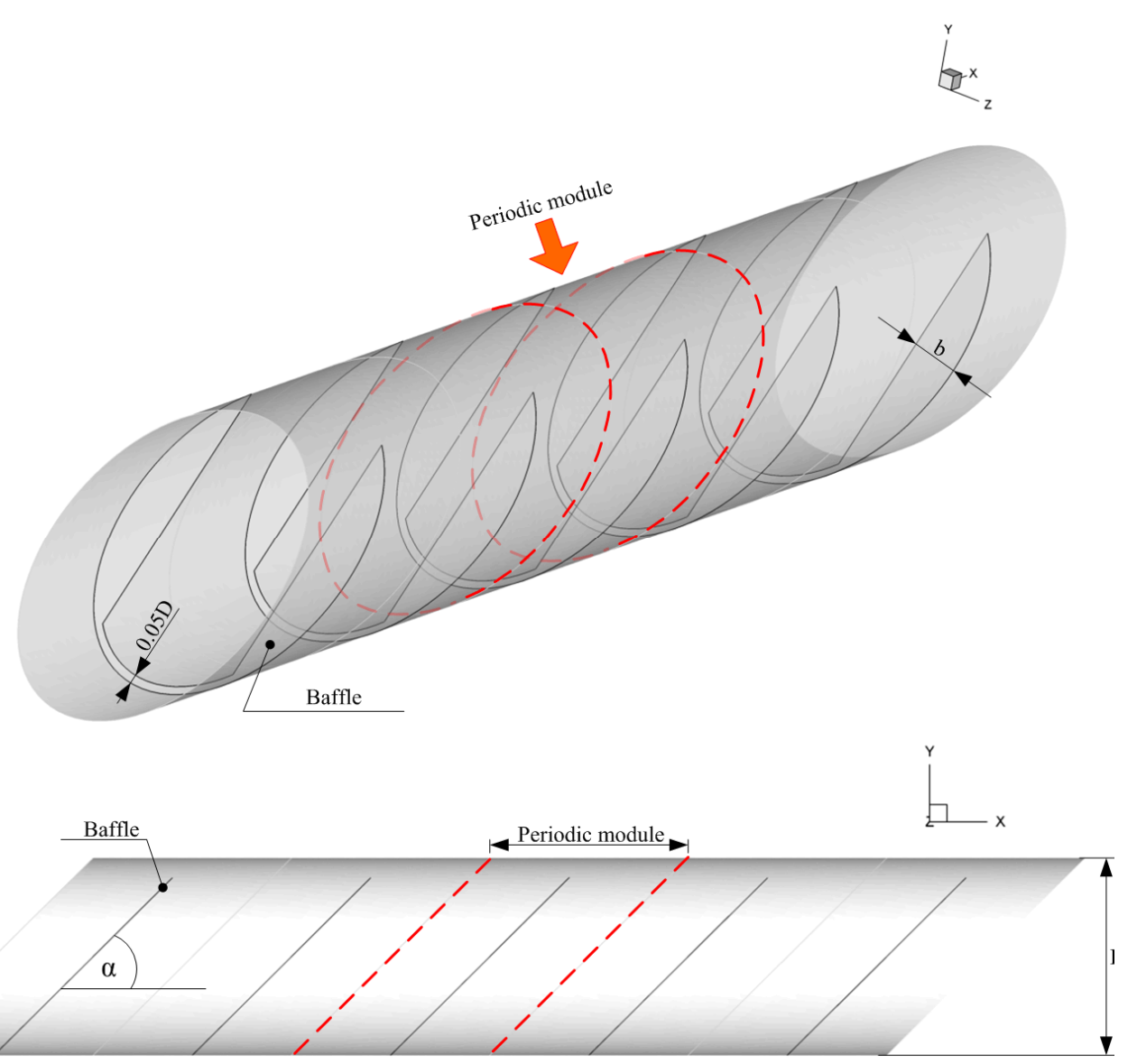

Fig. 1. Circular tube heat exchanger fitted with modified baffles

Table 2. Boundary condition of the computational domain

\begin{tabular}{ll}
\hline Zone & Boundary condition \\
\hline Inlet & Periodic \\
Outlet & Periodic \\
Tube wall & Constant temperature at 310K, \\
& no slip wall condition \\
U-shaped baffle & Insulator, no slip wall condition \\
\hline
\end{tabular}

The influences of the blockage ratio $(b / D$ or $B R=0.05$, $0.10,0.15 .0 .20$ and 0.25$)$ and flow attack angle $\left(\alpha=20^{\circ}\right.$, $30^{\circ}$ and $45^{\circ}$ ) of the U-shaped baffle on flow configuration and heat transfer characteristic are investigated. The laminar flow with the Reynolds number in range 100-1200 is considered.

\section{Boundary Condition and Assumption}

The boundary conditions for the computational domain of the tube heat exchanger fitted with the Ushaped baffle are written as Table 2 .

The assumptions for the present investigation are concluded as follows:

- Flow and heat transfer in the test tube are steady in three dimensions
- Flow is laminar and incompressible

- Body force, viscous dissipation, radiation heat transfer and natural convection are unnoticed.

- The test fluid is air with $300 \mathrm{~K}(\operatorname{Pr}=0.707)$

- The thermal properties of the air remain constant at average bulk mean temperature

\section{Mathematical Foundation}

The tube heat exchanger inserted with the U-shaped baffle is governed by the continuity, the Navier-Stokes equations and the energy equation.

The energy equation is discretized by the QUICK scheme, while the governing equations are discretized by power law scheme. The current investigation is resolved by finite volume method with SIMPLE algorithm. The solutions are measured to be converged when the normalized residual values are less than $10^{-5}$ for all variables, but less than $10^{-9}$ only for the energy equation.

The main parameters are Reynolds number, friction factor, local Nusselt number, average Nusselt number and thermal enhancement factor.

The Reynolds number is calculated as:

$\operatorname{Re}=\rho \bar{u} D / \mu$ 
The friction factor, $f$, is measured by pressure drop, $\Delta p$, across the periodic module, $L$ :

$$
f=\frac{(\Delta p / L) D}{\frac{1}{2} \rho \bar{u}^{2}}
$$

The local heat transfer is written as:

$$
N u_{x}=\frac{h_{x} D}{k}
$$

The average Nusselt number can be obtained by:

$$
N u=\frac{1}{A} \int N u_{x} \partial A
$$

The Thermal Enhancement Factor (TEF) is calculated by the augmentations on both heat transfer and friction factor at similar pumping power:

$$
T E F=\left.\frac{h}{h_{0}}\right|_{p p}=\left.\frac{N u}{N u_{0}}\right|_{p p}=\left(N u / N u_{0}\right) /\left(f / f_{0}\right)^{1 / 3}
$$

The $N u_{0}$ and $f_{0}$ is the Nusselt number and friction factor for the smooth circular tube, respectively.

\section{Numerical Validation}

The computational domain for the smooth circular tube heat exchanger is validated on both heat transfer rate and flow structure as reported in Fig. 2. The numerical schemes for the momentum; FOU, power law, SOU, are also compared. The numerical results reveal that the difference of the numerical scheme has no effect for the flow and heat transfer. The deviations on flow and heat transfer are found around \pm 0.3 and $\pm 0.5 \%$, respectively.
The difference of grid numbers; 80000, 120000, 180000,240000 and 360000 , for the computational domain of the tube heat exchanger inserted with the Ushaped baffle at $\alpha=30^{\circ}$ and $B R=0.15$ is compared. Fig. $3 \mathrm{a}$ and $\mathrm{b}$ show the comparisons of the computational domain with various grid cells for heat transfer rate and pressure loss, respectively. The results show that the increment of grid cell from 180000 to 240000 has no effect for heat transfer and friction loss. Therefore, the grid around 180000 is applied for all cases of the computational model when considered on both time for investigation and accuracy result.

\section{Numerical Result}

The numerical results for the circular tube heat exchanger inserted with the U-shaped baffle are reported in terms of mechanisms on flow and heat transfer. The performance assessment for the present investigation is also concluded.

\section{Flow and Heat Transfer Mechanisms}

The flow configuration in the circular tube heat exchanger fitted with the U-shaped baffles is presented in term of streamline in transverse planes as depicted in Fig. 4. As the figure, it is found that the U-shaped baffle can produce the vortex flow through the test section. The symmetry vortex flow with common-flow-down is detected due to the baffle symmetry. The position of the vortex core depends on the location in the test tube. The vortex flow in the heating section help a better fluid mixing that is the reason for heat transfer and performance augmentations. The similar flow structure is found in all cases of the present investigation, but the strength of the vortex flow is not equal.

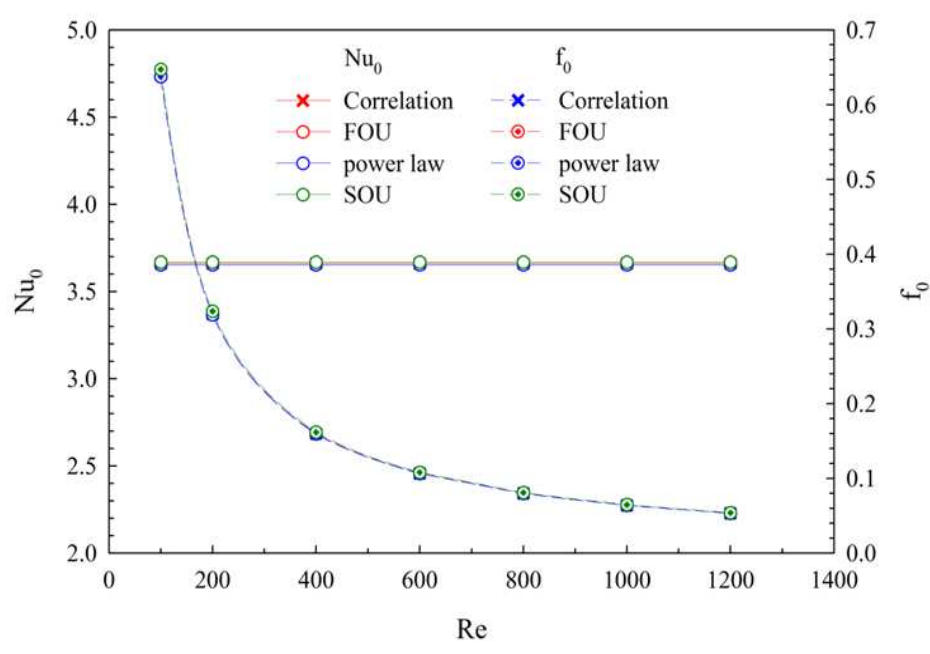

Fig. 2. Validation of the smooth circular tube 


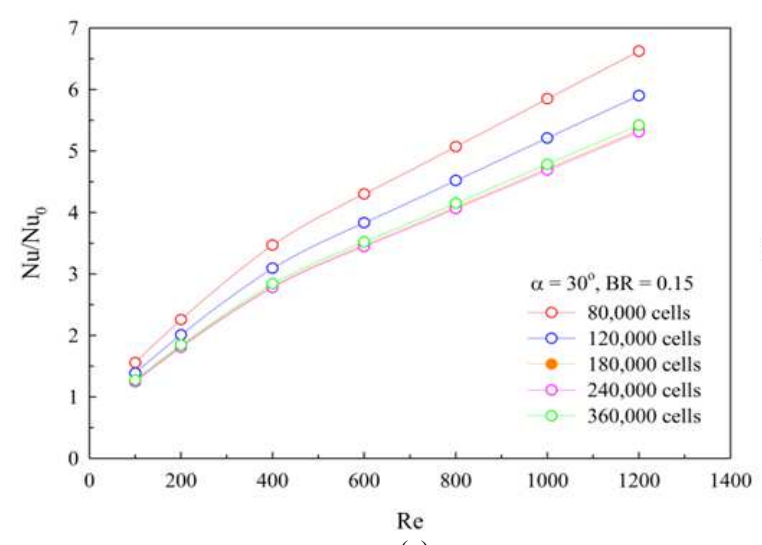

(a)

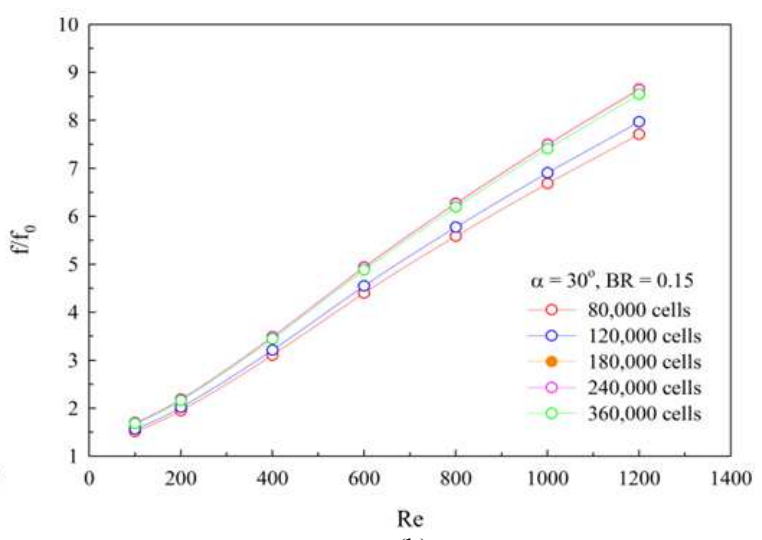

(b)

Fig. 3. Grid independence for (a) $N u / N u_{0}$ and (b) $f l f_{0}$ of the circular tube heat exchanger fitted with modified baffle at $\alpha=30^{\circ}$ and $B R$ $=0.15$

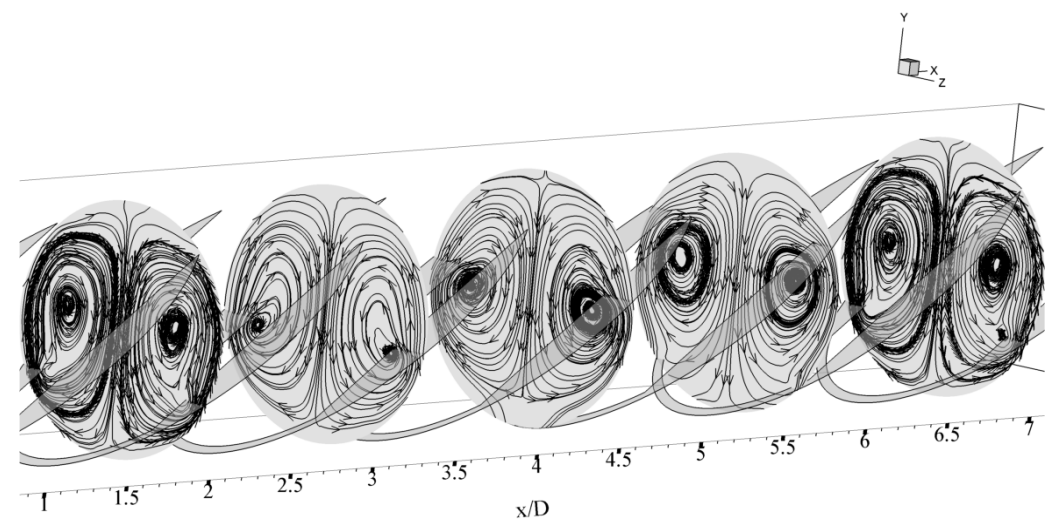

Fig. 4. Streamline in transverse planes for the circular tube heat exchanger fitted with modified baffle at $\alpha=30^{\circ}, B R=0.15$ and $R e=$ 600

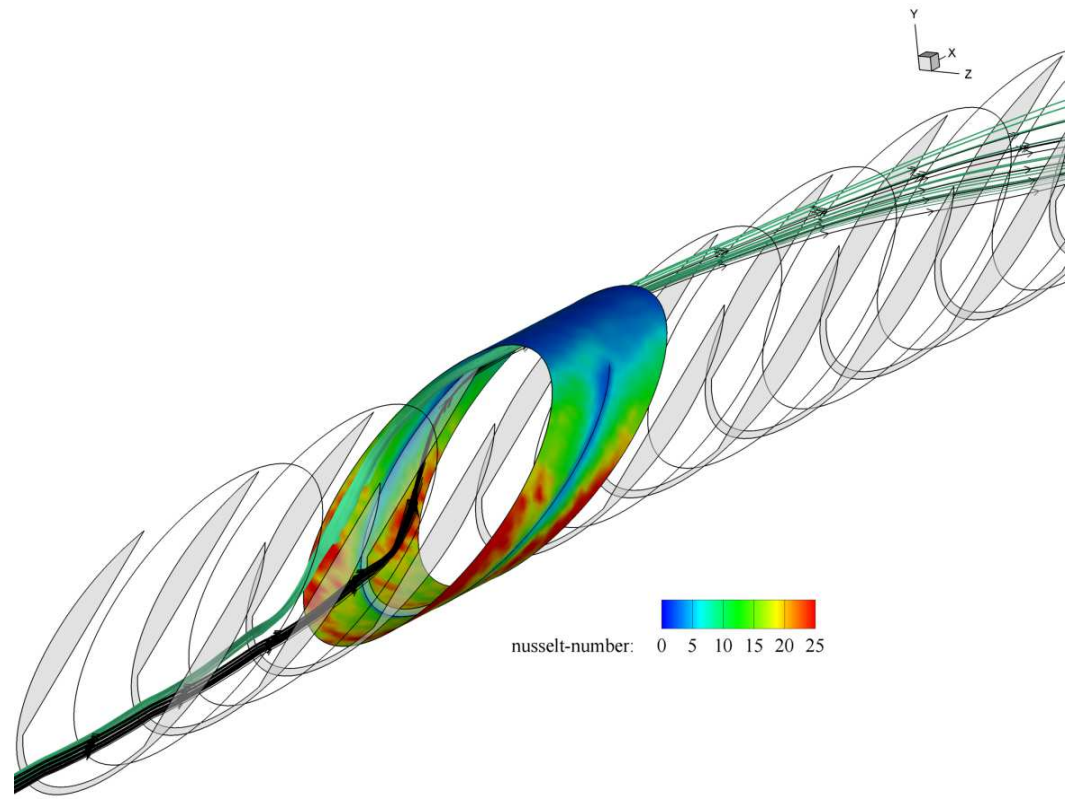

Fig. 5. Longitudinal vortex flow with local Nusselt number distribution on the tube wall for the circular tube heat exchanger fitted with modified baffle at $\alpha=30^{\circ}, B R=0.15$ and $R e=600$ 
Fig. 5 presents the local Nusselt number with longitudinal vortex flow in the tube heat exchanger fitted with U-shaped baffle at $\alpha=30^{\circ}, B R=0.15$ and $R e=600$. The local Nusselt number distribution is an indicator to describe the disturbance of the thermal boundary layer on the tube wall. The thermal boundary layer disturbance in the circular tube heat exchanger is cause for heat transfer rate and thermal performance improvements.

\section{Performance Analysis}

The performance analysis of the tube heat exchanger inserted with the U-shaped baffle on the Nusselt number ratio, friction factor ratio and thermal enhancement are reported as Figs. 6a, b and c, respectively.

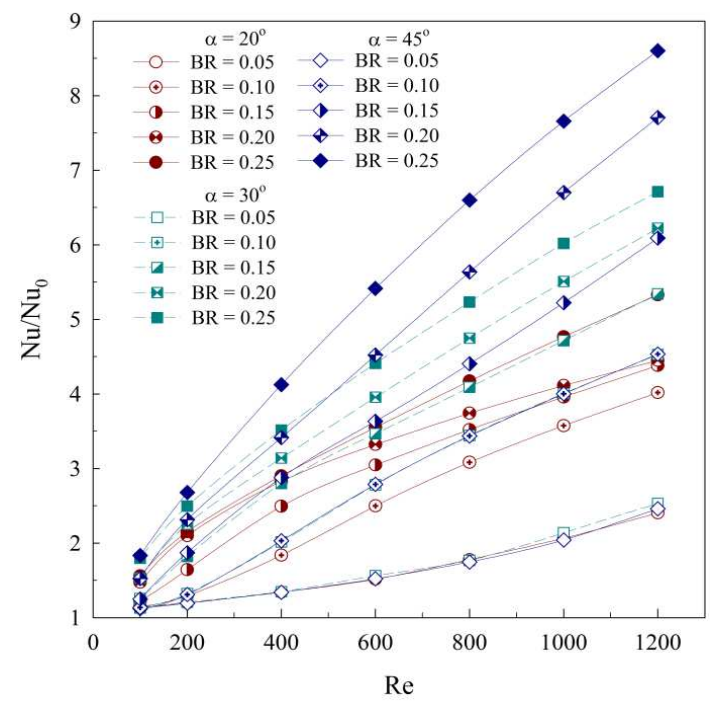

(a)
In general, the addition of the U-shaped baffle in the tube heat exchanger provides higher heat transfer rate, pressure loss and thermal performance than the smooth circular tube with no baffle. The Nusselt number ratio, friction factor ratio and thermal enhancement factor increases when increasing the Reynolds number for all cases.

Considering at similar flow attack angle, the heat transfer rate and friction loss increase when enhancing the baffle height. This is because the augmentation of the baffle height leads to increase vortex strength. The $B R=$ 0.25 of the U-shaped baffle performs the highest heat transfer rate and friction loss, while the $B R=0.05$ provides the opposite result.

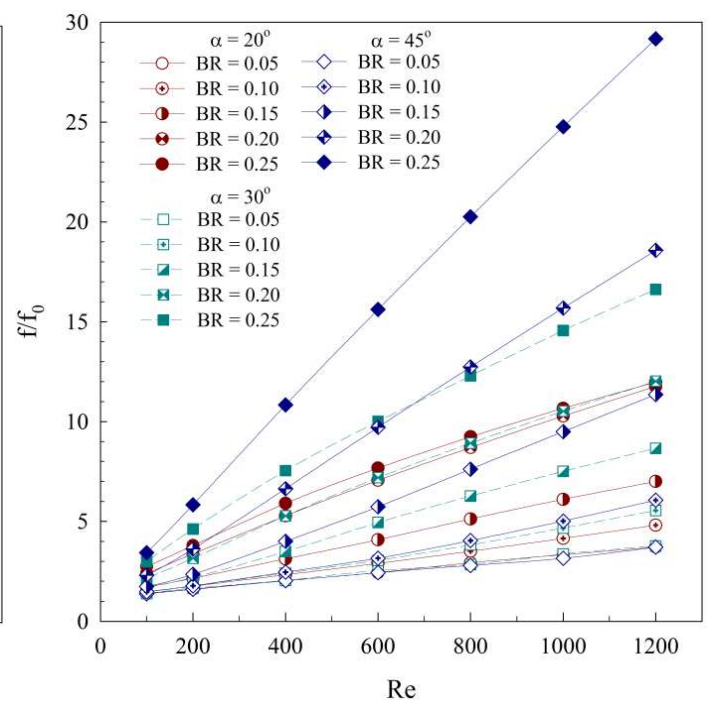

(b)

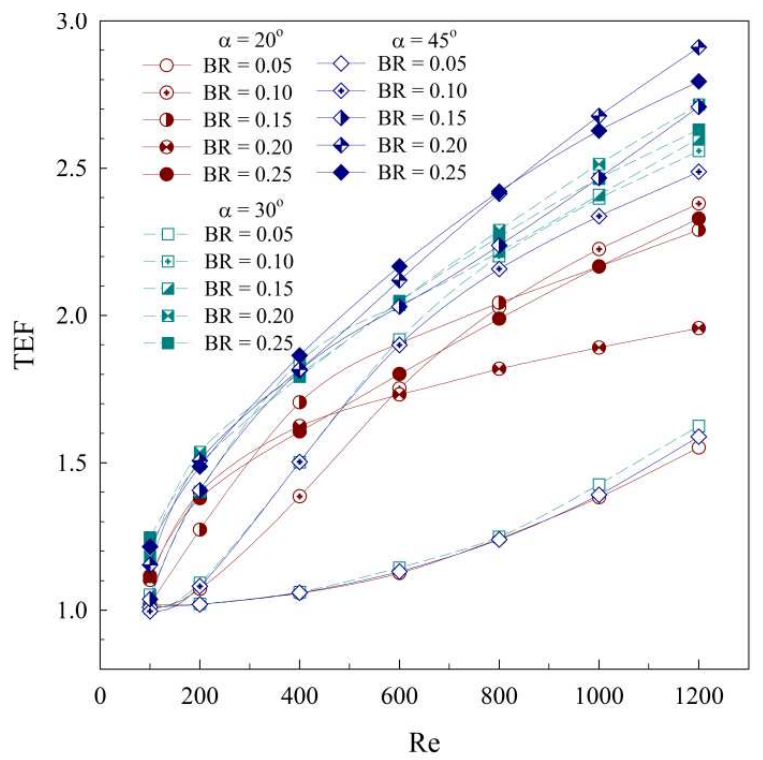

(c)

Fig. 6. Performance analysis: (a) $N u / N u_{0} \mathrm{Vs} R e$, (b) $f l f_{0} \mathrm{Vs} R e$ and (c) $T E F$ Vs $R e$ 
Considering at similar blockage ratio, the enhancements of heat transfer rate and friction loss are detected when increasing the flow attack angle of the Ushaped baffle, except for $B R=0.05$. The $45^{\circ} \mathrm{U}$-shaped baffle gives the highest heat transfer rate and pressure loss, while the $20^{\circ} \mathrm{U}$-shaped baffle provides the reverse result. The values on heat transfer rate and friction loss at $B R=0.05$ for all flow attack angles are closely found. In range studies, the heat transfer rate and friction loss are around 1-8.7 and 1-29 times above the smooth tube, respectively, depended on flow attack angle, blockage ratio and Reynolds number.

The addition of the U-shaped baffle in the circular tube heat exchanger enhances thermal enhancement factor higher than the smooth tube in all cases $(T E F>1)$. The optimum thermal enhancement factor is around 2.9 at $B R=0.2$ and $\alpha=45^{\circ}$ when considering at the highest Reynolds number, $R e=1200$. In range investigates, the thermal enhancement factor is found to be around 1-2.9 depended on the blockage ratio, flow attack angle and Reynolds number.

\section{Conclusion}

The article presents the numerical studies on flow and heat transfer characteristics in a circular tube heat exchanger inserted with the U-shaped baffle. The effects of height and flow attack angle for the U-shaped baffle on heat transfer, pressure loss and thermal performance are considered at laminar regime, $R e=100-1200$. The major findings are concluded as follows:

- The insertion of the U-shaped baffle can improve heat transfer rate and performance in the test section due to the vortex flow and impinging flow which created by the baffle

- The vortex strength increment is due to the augmentations on height and flow attack angle for the U-shaped baffle. The high vortex strength leads to higher heat transfer rate and pressure loss

- The heat transfer rate and friction loss are around 18.7 and 1-29 times over the smooth circular tube, respectively, when inserted the U-shaped baffle in the circular tube. The optimum thermal enhancement factor is detected at $45^{\circ}$ U-shaped baffle with the $B R=0.2$ around 2.9 at $R e=1200$

\section{Acknowledgement}

The authors would like to acknowledge Assoc. Prof. Dr. Pongjet Promvonge for suggestions.

\section{Funding Information}

The research was funded by King Mongkut's Institute of Technology Ladkrabang research fund and King Mongkut's University of Technology North Bangkok.

\section{Author's Contributions}

First Author: Designed the research plan and organized the investigation.

Second Author: Participated in all experiments and contributed to the writing of the manuscript.

\section{Ethics}

This article is original and contains unpublished material. The corresponding author confirms that all of the other authors have read and approved the manuscript and no ethical issues involved.

\section{References}

Akansu, S.O., 2006. Heat transfers and pressure drops for porous-ring turbulators in a circular pipe. Appl. Energ., 83: 280-298.

DOI: $10.1016 /$ j.apenergy.2005.02.003

Boonloi, A. and W. Jedsadaratanachai, 2013. 3D Numerical study on laminar forced convection in V-baffled square channel. Am. J. Appl. Sci., 10: 1287-1297. DOI: 10.3844/ajassp.2013.1287.1297

Boonloi, A., 2014. Effect of flow attack angle of V-ribs vortex generators in a square duct on flow structure, heat transfer and performance improvement. Modelling Simulation Eng. DOI: $10.1155 / 2014 / 985612$

Durmus, A., 2004. Heat transfer and exergy loss in cut out conical turbulators. Energ. Convers Manage., 45: 785-796. DOI: 10.1016/S0196-8904(03)00186-9

Eiamsa-ard, S. and P. Promvonge, 2006a. Experimental investigation of heat transfer and friction characteristics in a circular tube fitted with V-nozzle turbulators. Int. Commun. Heat Mass Transfer, 33: 591-600. DOI: 10.1016/j.icheatmasstransfer.2006.02.022

Eiamsa-ard, S. and P. Promvonge, 2006b. Effect of Vnozzle inserts and snail with free spacing entry on heat transfer in a heat exchanger. J. Energy Heat Mass Transfer, 28: 225-239.

Jedsadaratanachai, W. and A. Boonloi, 2013. Energy performance improvement, flow behavior and heat transfer investigation in a circular tube with $\mathrm{V}$ downstream discrete baffles. J. Math. Stat., 9: 339-348. DOI: $10.3844 /$ jmssp.2013.339.348

Jedsadaratanachai, W., S., Suwannapan and P. Promvonge, 2011. Numerical study of laminar heat transfer in baffled square channel with various pitches. Energy Procedia, 9: 630-642. DOI: $10.1016 /$ j.egypro.2011.09.073

Kiml, R., A. Magda, S. Mochizuki and A. Murata, 2004. Rib-induced secondary flow effects on local circumferential heat transfer distribution inside a circular rib-roughened tube. Int. J. Heat Mass Transfer, 47: 1403-1412.

DOI: 10.1016/j.ijheatmasstransfer.2003.09.026 
Kiml, R., S. Mochizuki, A. Murata and V. Stoica, 2003. Effects of rib-induced secondary flow on heat transfer augmentation inside a circular tube. J. Enhanc. Heat Transfer, 10: 9-20. DOI: 10.1615/JEnhHeatTransf.v10.i1.20

Kongkaitpaiboon, V., K. Nanan and S. Eiamsa-ard, 2010a. Experimental investigation of convective heat transfer and pressure loss in a round tube fitted with circular-ring turbulators. Int. Commun. Heat Mass Transfer, 37: 568-574.

DOI: 10.1016/j.icheatmasstransfer.2009.12.016

Kongkaitpaiboon, V., K. Nanan and S. Eiamsa-ard, 2010b. Experimental investigation of heat transfer and turbulent flow friction in a tube fitted with perforated conical rings. Int. Commun. Heat Mass Transfer, 37: 560-567.

DOI: 10.1016/j.icheatmasstransfer.2009.12.015

Kwankaomeng, S. and P. Promvonge, 2010. Numerical prediction on laminar heat transfer in square duct with $30^{\circ}$ angled baffle on one wall. Int. Commun. Heat Mass Transfer, 857-866.

DOI: $10.1016 /$ j.icheatmasstransfer.2010.05.005

Ozceyhan, V., S. Gunes, O. Buyukalaca and N. Altuntop, 2006. Heat transfer enhancement in a tube using circular cross sectional rings separated from wall. Appl. Energ., 83: 280-298.

DOI: $10.1016 /$ j.apenergy.2008.02.007

Promvonge, P. and S. Eiamsa-ard, 2007a. Heat transfer augmentation in a circular tube using V-nozzle turbulator inserts and snail entry. Exp. Therm. Fluid Sci., 32: 332-340.

DOI: $10.1016 /$ j.expthermflusci.2007.04.010

Promvonge, P. and S. Eiamsa-ard, 2007b. Heat transfer and turbulent flow friction in a circular tube fitted with conical-nozzle turbulators. Int. Commun. Heat Mass Transfer, 34: 72-82.

DOI: 10.1016/j.icheatmasstransfer.2006.08.003

Promvonge, P. and S. Eiamsa-ard, 2007c. Heat transfer in a circular tube fitted with free spacing snail entry and conical-nozzle turbulators. Int. Commun. Heat Mass Transfer, 34: 838-848.

DOI: $10.1016 /$ j.icheatmasstransfer.2007.03.020

Promvonge, P. and S. Eiamsa-ard, 2007d. Heat transfer behaviors in a tube with combined conical-ring and twisted-tape insert. Int. Commun. Heat Mass Transfer, 34: 849-859.

DOI: 10.1016/j.icheatmasstransfer.2007.03.019

Promvonge, P. and S. Kwankaomeng, 2010. Periodic laminar flow and heat transfer in a channel with $45^{\circ}$ staggered V-baffles. Int. Commun. Heat Mass Transfer, 37: 841-849.

DOI: $10.1016 /$ j.icheatmasstransfer.2010.04.002

Promvonge, P., S. Sripattanapipat and S. Kwankaomeng, 2010. Laminar periodic flow and heat transfer in square channel with 450 inline baffles on two opposite walls. Int. J. Therm. Sci., 49: 963-975. DOI: $10.1016 /$ j.ijthermalsci.2010.01.005
Promvonge, P., W. Jedsadaratanachai and S. Kwankaomeng, 2010. Numerical study of laminar flow and heat transfer in square channel with $30^{\circ}$ inline angled baffle turbulators. Appl. Therm. Eng., 30: 1292-1303.

DOI: 10.1016/j.applthermaleng.2010.02.014

Promvonge, P., W. Jedsadaratanachai, S. Kwankaomeng and C. Thianpong, 2012. 3D simulation of laminar flow and heat transfer in V-baffled square channel. Int. Commun. Heat Mass Transfer, 39: 85-93. DOI: 10.1016/j.icheatmasstransfer.2011.09.004

Yakut, K. and B. Sahin, 2004a. Flow-induced vibration analysis of conical-rings used of heat transfer enhancement in heat exchanger. Appl. Energ., 78: 273-288. DOI: 10.1016/j.apenergy.2003.09.001

Yakut, K., B. Sahin and S. Canbazoglu, 2004b. Performance and flow-induced vibration characteristics for conical-ring turbulators. Appl. Energ., 79: 65-76.

DOI: $10.1016 / \mathrm{j}$.apenergy.2003.11.002

\section{Nomenclature}

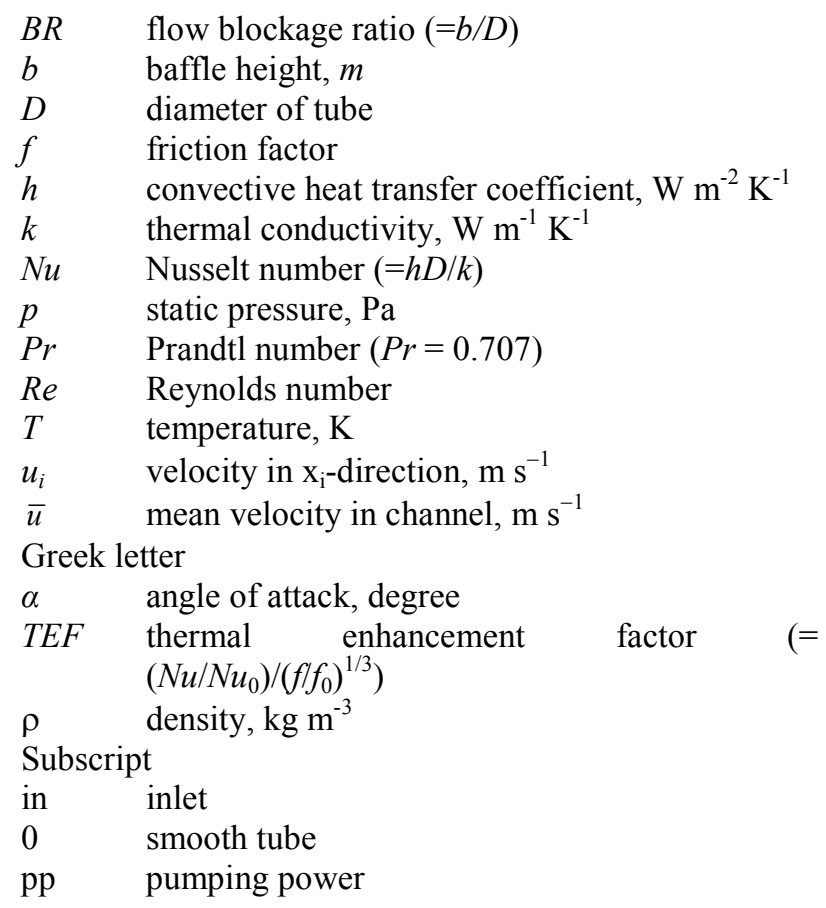

